mental investigations in civil engineering; to Baghdad College, $£ 50,000$ towards a Gulbenkian science block for the new Jesuit university (Al-Hikma University); to the Sanatorium of Azounieh, Lebanon, £20,000 over three yoars for building a Calouste Gulbenkian Research Centre for Chest Diseases, to serve the Middle East, $£ 10,000$ for laboratory equipment, and $£ 6,000$ over three years towards the running expenses; to the Faculty of Medicine, University of Lisbon, $£ 22,500$ to install, equip and maintain for three years a laboratory of electron microscopy in the Institute of Histology and Embryology, and $£ 18,500$ to the Laboratory of Physiological Chemistry for essontial materials and research; for a new Centre for Agricultural Economics in Portugal, $\mathfrak{£ 1 5 , 0 0 0}$ initially to establish and run the new centre as part of the Foundation's own activities ; to the Sarawak Museum, British Borneo, $£ 5,000$ for the excavation during 1958 of the great cave of Niah in Subis Mountain (see Man, 57, 161, November 1957); to the Institute of Archæology, Faculty of Arts, University of Coimbra, $£ 2,500$ for archæological research in Iraq; to the Office of Town-Planning Research, Lisbon, £1,250 a year for three years. Other grants include Gulbenkian Fellowships, for which $£ 15,000$ has been set aside in the United Kingdom for three year's to oncourage co-operation between selected universities and teachers of mathematics, science and technology in nearby schools, technical colleges and training colleges, with the view of improving the quantity and quality of science teaching; and grants to undergraduate scientific expeditions from the United Kingdom, for which up to $£ 2,600$ will be granted over throe years. The two expeditions assisted this year have been from the University of Cambridge to the Colombian Cordillera Oriental and to French West Africa. $£ 2,000$ has been allocated to the Mathematical Association, to finance the publication of the Association's authoritative reports and recommendations.

\section{Indonesian Council for the Sciences}

A Council has been established by Act of the Republic of Indonesia, under the name of "Madjelis Ilmu Pengetahuan Indonesia", to work in the scientific field in Indonesia. The tasks of this Council include: the promotion of science in Indonesia; advising the Government in scientific matters; encouraging the exchange of scientific information between Indonesia and the rest of the world; the direction of institutes; and the allocation of funds entrusted to it. Further information can be obtained from the Information Department of the Indonesian Council for Sciences, Medan Merdeka Selatan 11 pav., Djakarta.

\section{Announcements}

OwIng to other commitments, the Rev. C. E. Raven has retired from the presidoncy of the Field Studies Council. The Rt. Hon. Lord Hurcomb has agreed to fill the office with effect from November 1.

THF Textile Institute has made the following awards : Institute Medal to Mr. G. Loasby, chairman of the Council of the Institute since 1955, in recognition of distinguished services to the textile industry in general, and to the Textile Institute in particular; Service Medal to Mr. H. Pomfret, honorary secretary of the Blackburn Section of the Institute for eleven years ; and to Dr. P. P. Townend, Department of Textile Industries, University of Leeds, a former chairman of the Yorkshire Section of the Institute.

THe nineteenth annual congress of the British Institute of Radiology will be held at the Royal Horticultural Halls and the Napier Hall, Westminster, during November 27-29. Further information can be obtained from the General Secretary, British Institute of Radiology, 32 Welbeck Street. London, W.1.

A PROGRAMME of sciontific films in colour, organized by the Society of Chemical Industry, will be shown at the Royal Empire Society, 18 Northumberland Avenue, W.C.2, on November 18, at 6.30 p.m. The films to be shown include "Canadian Wheat" (National Film Board of Canada) ; "Point of New Doparture" (Imperial Chemical Industries Ltd.) on synthetio fibres with emphasis on 'Teryleno'; "Coral Wonderland" (Australian Nows and Information Bureau); and "A Vitamin Energes" (Glixo Laboratories Ltd.) on the story of vitamin $B_{12}$. The meeting is open to members of the Society, who may bring friends.

A JoINT symposium on "Rocent Developments in Industrial Low Temperature Gas Separation" organized by the Institution of Chemical Engineers and by the Low Temperature Group of the Physical Society, is to bo held at the Royal Institution, Albemarle Street, London, W.I, on November 26. The papers read at the meeting will be published, together with a report of the discussion, in the Transactions of the Institution of Chemical Engineers. Further details and registration forms for those wishing to attend the symposium may be obtained from the Physical Society, 1 Lowther Gardens, London, S.W.7, or from the Institution of Chemical Engineers, I6 Belgravo Square, London, S.W.1.

THE first Sherrington Memorial Lecture of the Royal Society of Medicine will be delivered by Lord Adrian at 8 p.m. on November 27 in the Barnes Hall. The subject of the Lecture will be "The Analysis of the Nervous System". Admission to the Lecture, which is open to Fellows of tho Society and their guests, is by ticket, obtainable from the Royal Society of Medicine, 1 Wimpole Street, London, W.1.

UNDER the provisions of the Fulbright Programme, travel grants are available to eitizens of the United Kingdom and British Colonies to go to tho United States for an academic or educational purpose, provided that they have the financial support in dollars for the visit, and have been accepted by an American institution of higher learning. The grants cover the cost of direct travel between the candidate's home and the United States and return, and are available during June 1, 1958-April 1, 1959. Applications must be submitted by March 15, 1958 (for those travelling between June 1 and August 15, 1958) or by June 1 (for those travelling after August I6). Application forms and further information ean be obtained from the United States Educational Commissicn in the United Kingdom, 71 South Audley Street, London, W.l.

ERratum. In the article on the orbit of the first Russian Earth satellite in Nature of Novornber 9, there is an error in tho time of transit givon in the last line of Table 1 on p. 938 : for " $05 \mathrm{hr} .29 \mathrm{~min}$. 22 sec." read "05 hr. $28 \mathrm{~min} .30$ sec.". 